\title{
PENGARUH CAR, NPF DAN FDR TERHADAP PROFITABILITAS BANK SYARIAH (Studi Kasus Pada Bank BCA Syariah Tahun 2010-2017)
}

\author{
Abdul Haris Romdhoni, Bunga Chairunisa Chateradi \\ STIE AAS Surakarta \\ Email: harisromdhoni27@yahoo.com
}

\begin{abstract}
This study aims to determine the effect of Capital Adequacy Ratio (CAR), Non Performing Financing (NPF), Financing to Deposit Ratio (FDR) to profitability at Bank BCA Syariah year 2010-2017 either partially or simultaneously. The population in this study is Bank BCA Syariah in 2010-2017 as many as 30 samples taken by purposive sampling. Data used using secondary data obtained from quarterly financial report of Bank BCA Syariah. The method used in this research is by using classical assumption test method where the classical assumption test consist of four test that is Normality test, Multicolinierity test, Heterokedasticity test, Autocorrelation test besides using Classic Assumption test, in this research also use test with data analysis from analysis multiple linear regression and using $t$ test or partial test and $F$ test or together. The results showed that the variables affecting profitability are Capital Adequacy Ratio (CAR) with P-value of 0.000 and t-count equal to -4.206 where this value is bigger than t-table 2.05553, while the variable that has no effect on profitability is a Non Performing Financing (NPF) variable with a value of P-value of 0.105 where this value is greater than 0.05 and t-count is smaller than t-table and Financing to Deposit Ratio (FDR) variable with $P$-value value of 0.362 where this value is greater than 0.05 and $t$-count is smaller than t-table. Simultaneously all variables CAR, NPF and FDR jointly affect the profitability of Bank BCA Syariah year 2010-2017.
\end{abstract}

Keywords: CAR, NPF, FDR, Profitability.

\section{PENDAHULUAN}

Bank merupakan lembaga keuangan yang menghimpun dana dari masyarakat dan menyalurkan dana untuk masyarakat. Dengan adanya lembaga keuangan perbankan dapat membantu kehidupan masyarakat dalam hal ekonomi, mulai dari menanamkan sebagian dana terhadap bank yaitu dengan menabung dan berinvestasi serta membantu dalam pengajuan kredit maupun pembiayaan. Berdasarkan Undang-Undang No. 10 Tahun 1998, bank dalam melaksanakan kegiatan usahanya secara konvensional atau berdasarkan prinsip syariah.

Perkembangan bank syariah pada artikel di Kompasiana tanggal 5 Mei 2016, menyatakan Indonesia merupakan mayoritas penduduk yang beragama Islam sehingga Indonesia sebagai pasar yang potensial dalam pengembangan keuangan syariah. Lembaga keuangan bank yang kegiatan operasionalnya menggunakan prinsip syariah saat ini sudah mulai berkembang pesat. Perbankan syariah di Indonesia diproyeksikan akan meningkat seiring dengan meningkatnya laju ekspansi kelembagaan dan akselerasi pertumbuhan aset perbankan syariah yang sangat tinggi dan ditambah lagi dengan volume penerbitan sukuk yang terus meningkat berdasarkan data yang diperoleh dari Islamic Finance Country Index (IFCI). Di Indonesia memiliki keunggulan struktur pengembangan keuangan syariah adalah regulasinya dimana kewenangan mengeluarkan fatwa keuangan syariah terpusat pada satu lembaga independen yaitu Dewan Syariah Nasional dari Majelis Ulama Indonesia (MUI) berbeda dengan di negara lain fatwa dapat dikeluarkan oleh 
perorangan ulama sehingga kemungkinan terjadinya perbedaan regulasi satu sama lain lebih besar.

Dewan Syariah Nasional-Majelis Ulama Indonesia (DSN-MUI) dibentuk dalam rangka mewujudkan aspirasi umat Islam mengenai masalah perekonomian dan mendorong penerapan ajaran Islam dalam bidang perekonomian/keuangan yang dilaksanakan sesuai dengan tuntunan syariat Islam. Selain Dewan Syariah Nasional-MUI lembaga independen lain yang turut andil dalam kegiatan perbankan syariah adalah Dewan Pengawas Syariah (DPS). Dewan pengawas syariah merupakan institusi independen dalam bank syariah yang fungsi utamanya adalah melakukan pengawasan kepatuhan syariah dalam operasional bank syariah.

Bank syariah dalam menyediakan produk-produk perbankan yang ditawarkan tidak ada yang bersifat spekulatif atau hanya mencari keuntungan semata sehingga tidak akan terpengaruh oleh krisis ekonomi global. Bank syariah di Indonesia dalam pembiayaan lebih kepada sektor riil sehingga memberikan pengaruh yang lebih besar terhadap pertumbuhan ekonomi. Kedepannya bank syariah yang ada di Indonesia diharapkan mampu meningkatkan kemandirian agar dapat berdiri secara independen dan bank induknya kegiatan operasionalnya dapat dikelola secara profesional dan mandiri menggunakan prinsip yang benar-benar syariah. Dengan berkembangnya bank syariah yang terdapat di Indonesia dan minat nasabah dalam bertransaksi di bank syariah dapat meningkatkan profitabilitas bank syariah di Indonesia. Cara yang digunakan untuk mengukur profitabilitas adalah rasio return on equity (ROE) menurut Pramudhito (2014) menunjukkan kemampuan bank dalam mengelola modal yang tersedia untuk mendapatkan net income yang dimiliki oleh bank syariah.

Capital Adequacy Ratio (CAR) dapat mempengaruhi profitabilitas bank tersebut. Semakin besar CAR maka semakin besar kesempatan bank dalam menghasilkan laba karena dengan modal yang besar, manajemen bank sangat leluasa dalam menempatkan dananya kedalam aktivitas investasi yang menguntungkan. Non Performing Financing (NPF) merupakan rasio yang digunakan untuk mengukur risiko terhadap kredit yang disalurkan dengan membandingkan pembiayaan bermasalah dengan jumlah pembiayaan yang disalurkan.

NPF diperuntukkan bagi bank syariah, sementara NPL (Non Performing Loan) diperuntukkan bagi bank umum konvensional. Semakin tinggi rasio ini, maka semakin buruk kualitas pembiayaan sebuah bank (Azmi, 2014). Financing to Deposit Ratio (FDR) merupakan perbandingan antara pembiayaan yang diberikan oleh bank dengan dana pihak ketiga yang berhasil dikerahkan oleh bank (Hasibuan, 2006). Tinggi rendahnya rasio FDR menunjukkan tingkat likuiditas bank tersebut (Pramudhito, 2014). Semakin tinggi dana yang disalurkan bank dalam bentuk pembiayaan, maka semakin tinggi pula kemampuan bank dalam memberikan pinjaman.

\section{KAJIAN PUSTAKA Lembaga Keuangan}

Menurut Dahlan Siamat dalam (Susanto, 2015) lembaga keuangan adalah badan usaha yang kekayaannya itu dalam bentuk aset keuangan dibanding asset non-finansial atau riil. Dimana lembaga keuangan sudah memberikan kredit atau pembiayaan terhadap nasabah dan menanamkan dananya pada surat yang berharga. Dengan adanya lembaga keuangan maka kehidupan masyarakat dalam hal ekonomi akan lebih sedikit membantu karena apabila masyarakat atau nasabah ingin mengajukan pembiayaan atau kredit dapat dengan mudah. 


\section{Bank Syariah}

Kata bank berasal dari kata banque dalam bahasa Prancis, dan dari banco dalam bahasa Italia, yang dapat berarti peti, lemari dan bangku. Konotasi kedua kata ini menjelaskan dua fungsi dasar yang ditunjukkan oleh bank komersial. Kata peti atau lemari menyiratkan fungsi sebagai tempat menyimpan benda-benda berharga seperti peti emas, peti berlian, peti uang dan sebagainya (Arifin, 2003: 1).

Bank syariah adalah bank yang melaksanakan kegiatan usaha berdasarkan prinsip syariah, yaitu aturan perjanjian berdasarkan hukum Islam antara bank dan pihak lain untuk penyimpanan dana dan pembiayaan kegiatan usaha, atau kegiatan lainnya yang dinyatakan sesuai dengan prinsip syariah. Pembentukan sistem perbankan syariah ini berdasarkan adanya larangan dalam agama Islam untuk meminjamkan atau memungut pinjaman dengan mengenakan bunga pinjaman (riba), serta larangan untuk berinvestasi pada usaha-usaha berkategori terlarang (haram) atau dalam kata lain bank syariah adalah suatu lembaga keuangan yang usaha pokoknya memberikan kredit dan jasa-jasa dalam lalu lintas pembayaran serta peredaran uang yang pengoperasiannya disesuaikan dengan prinsip-prinsip syariat Islam (Sumitro, 2002: 5).

\section{Perbedaan Bank Konvensional dan Bank Syariah}

Secara garis besar perbandingan bank konvensional dengan bank syariah dapat dilihat pada tabel berikut (Mahmud dan Rukmana, 2010: 56):

Tabel 1.1

Perbandingan Bank Konvensional dan Bank Syariah

\begin{tabular}{|c|c|c|}
\hline Aspek & Bank Konvensional & Bank Syariah \\
\hline Legalitas & Akad konvensional & Akad syariah \\
\hline Struktur Organisasi & $\begin{array}{l}\text { Tidak terdapat dewan } \\
\text { sejenis }\end{array}$ & $\begin{array}{l}\text { Penghimpunan dan } \\
\text { penyaluran dana harus } \\
\text { sesuai dengan fatwa } \\
\text { dewan pengawas } \\
\text { syariah }\end{array}$ \\
\hline $\begin{array}{l}\text { Bisnis dan Usaha } \\
\text { Yang Dibiayai }\end{array}$ & $\begin{array}{l}\text { Investasi yang halal } \\
\text { dan haram profit } \\
\text { oriented, hubungan } \\
\text { nasabah dalam bentuk } \\
\text { hubungankreditur- } \\
\text { debitur, memakai } \\
\text { perangkat bunga. }\end{array}$ & $\begin{array}{l}\text { Melakukan investasi- } \\
\text { investasi yang halal } \\
\text { saja, hubungan dengan } \\
\text { nasabah dalam bentuk } \\
\text { hubungan kemitraan, } \\
\text { berdasarkan prinsip } \\
\text { bagi hasil, jual beli } \\
\text { atau sewa, berorientasi } \\
\text { pada keuntungan dan } \\
\text { kemakmuran serta } \\
\text { kebahagiaan dunia } \\
\text { akhirat }\end{array}$ \\
\hline Lingkungan Kerja & Non Islami & Islami \\
\hline
\end{tabular}




\section{Perbedaan Bunga Bank dan Bagi Hasil}

Bunga merupakan harga yang harus dibayar/ diterima untuk meminjam/ menyimpan uang selama periode tertentu dan biasanya dinyatakan dalam persentase uang yang dipinjam/ disimpan. Sementara bagi hasil adalah hasil (untung/rugi) yang diperoleh atas suatu proyek yang dibiayai oleh Bank maupun peminjam dibagi sesuai dengan ketentuan akad yang telah disepakati bersama.

Perbedaan sangat mendasar antara sistem bunga dengan bagi hasil adalah pada sistem bunga dalam bank konvensional, penentuan bunga dibuat pada waktu akad tanpa berpedoman pada kesepakatan bersama (pihak bank yang menentukan) dan apakah perhitungan sistem bunga dapat menyulitkan nasabah untuk membayar angsuran atau tidak. Sedangkan pada sistem bagi hasil penentuan resiko keuntungan berdasarkan kesepakatan bersama antara pihak bank dengan nasabah dengan berpedoman pada kemungkinan tidak memberatkan pihak nasabah dalam mengangsur dana tidak merugikan pihak bank.

Pada sistem bunga, suku pinjaman bank konvensional dan suku bunga simpanan masingmasing akan saling mempengaruhi. Maka apabila suku bunga simpanan tinggi otomatis suku bunga pinjaman ikut tinggi. Sedangkan dalam sistem bagi hasil tidak demikian. Pada sistem bunga, tinggi rendahnya bunga dipengaruhi oleh target laba (keuntungan) yang diinginkan oleh pihak bank, jadi apabila laba yang di inginkan besar maka bunga ikut besar pula dan sebaliknya, sedangkan pada sistem bagi hasil tidak adanya demikian (Zuhri, 1996:166).

\section{Profitabilitas}

Kinerja keuangan dapat diukur dari profitabilitas industri. Rasio profitabilitas yang semakin tinggi dapat menarik pendatang baru untuk masuk ke dalam industri, karena profitabilitas merupakan indikator yang paling tepat untuk mengatur kinerja suatu bank (Sofyan, 2003). Seluruh manajemen bank, baik yang mencakup manajemen permodalan, manajemen kualitas aktiva, manajemen umum, manajemen rentabilitas dan manajemen likuiditas pada akhirnya akan mempengaruhi pada perolehan laba (profitabilitas) pada perusahaan perbakan. Profitabilitas adalah kemampuan perusahaan untuk menghasilkan laba dengan menggunakan aktiva atau modal yang dimilikinya.

Return On Equity (ROE) merupakan salah satu instrument analisis rasio keuangan yang dipergunakan untuk mengukur efisiensi kinerja perusahaan dan tingkat profitabilitas suatu perusahaan. Semakin tinggi Return On Equity maka semakin baik kinerja keuangan perusahaan karena kenaikan laba bersih lebih besar dibandingkan dengan kenaikan equity.

Rasio ini menggunakan hubungan antara keuntungan setelah pajak dengan modal sendiri yang digunakan perusahaan. Yang dianggap modal sendiri adalah saham biasa, agio saham, laba ditahan, saham preferen dan cadangan-cadangan lain. Return On Equity diperoleh dari Net Income after tax dibagi equity. Semakin tinggi rasio ini menandakan kinerja perusahaan semakin baik atau efisien, nilai equity perusahaan akan meningkat dengan peningkatan rasio ini. ROE menunjukkan kemampuan manajemen bank dalam mengelola modal yang tersedia untuk mendapatkan net income.

Semakin tinggi return semakin baik, berarti dividen yang dibagikan atau ditanamkan kembali sebagai retained earning juga semakin besar (Kuncoro, 2002: 551). ROE membandingkan laba bersih setelah pajak dengan ekuitas yang telah di investasikan. ROE yang tinggi sering kali mencerminkan penerimaan perusahaan atas peluang investasi yang baik dan manajemen biaya yang efektif. Sedangkan pihak-pihak yang berkepentingan untuk mengetahui 
tingkat profitabilitas adalah (a) masyarakat, (b) pemegang saham, (c) perpajakan, (d) pemerintah, (e) karyawan dan (f) manajemen bank.

\section{Capital Adequacy Ratio (CAR)}

Capital Adequacy Rasio (CAR) merupakan rasio kinerja bank untuk mengukur kecukupan modal yang dimiliki oleh bank untuk menunjang aktiva yang mengandung atau menghasilkan resiko. Modal merupakan salah satu faktor penting dalam rangka pengembangan usaha bisnis dan menampung resiko kerugian, semakin tinggi CAR maka semakin kuat kemampuan bank tersebut untuk menanggung resiko dari setiap kredit/ aktiva produktif yang berisiko (Ruslim, 2012). Semakin besar CAR maka semakin besar kesempatan bank dalam menghasilkan laba karena dengan modal yang besar, manajemen bank sangat leluasa dalam menempatkan dananya kedalam aktivitas investasi yang menguntungkan.

CAR mencerminkan modal sendiri perusahaan untuk menghasilkan laba. Semakin besar CAR maka semakin besar kesempatan bank dalam menghasilkan laba karena dengan modal yang besar, manajemen bank sangat leluasa dalam menempatkan dananya kedalam aktivitas investasi yang menguntungkan. Pembentukan dan peningkatan peranan aktiva bank sebagai penghasil keuntungan harus memperhatikan kepentingan pihak-pihak ketiga sebagai pemasok modal bank. Dengan demikian bank harus menyediakan modal minimum yang cukup untuk menjamin kepentingan pihak ketiga (Sinungan, 2000: 162).

\section{Non Performing Financing (NPF)}

Non Performing Financing (NPF) yaitu suatu risiko yang dikaitkan dengan kemungkinan kegagalan klien membayar kewajibannya atau risiko dimana debitur tidak dapat melunasi hutangnya (Ghozali, 2007). Semakin tinggi rasio ini, maka semakin buruk kualitas pembiayaan sebuah bank (Azmi, 2014). Tingginya NPF menunjukkan bahwa bank tersebut tidak profesional dalam mengelola pembiayaannya, sehingga hal ini memberikan indikasi bahwa tingkat risiko atas pemberian pembiayaan pada bank tersebut cukup tinggi searah dengan NPF yang dihadapi (Pratiwi, 2012). Dikarenakan pembiayaan merupakan sektor terbesar dalam menyumbang pendapatan bank.

Semakin tinggi pembiayaan bermasalah pada bank syariah, maka pendapatan yang diterima oleh bank tersebut akan berkurang, hal ini berakibat pada menurunnya profitabilitas bank syariah. Pengelolaan pembiayaan sangat diperlukan oleh bank, mengingat fungsi pembiayaan sebagai penyumbang pendapatan terbesar bagi bank syariah. Bertambahnya NPF akan mengakibatkan hilangnya kesempatan untuk memperoleh pendapatan dari pembiayaan yang diberikan sehingga mempengaruhi perolehan laba dan berpengaruh buruk pada ROE.

\section{Financing to Deposit Ratio (FDR)}

Financing To Deposit Ratio (FDR) merupakan kemampuan bank dalam menyalurkan dananya kepada pihak yang membutuhkan modal (Kasmir, 2009). Tinggi rendahnya rasio FDR menunjukkan tingkat likuiditas bank tersebut (Pramudhito, 2014). Bank Indonesia menetapkan FDR yang ideal berkisar antara $78 \%$ hingga $100 \%$. Semakin tinggi dana yang disalurkan bank dalam bentuk pembiayaan, maka semakin tinggi pula kemampuan bank dalam memberikan pinjaman.

Hal ini berdampak pada peningkatan pendapatan, sehingga keuntungan perbankan syariah semakin meningkat. Namun, apabila pembiayaan yang disalurkan oleh bank tersebut rendah, 
maka dapat dikatakan bahwa tingkat likuiditas bank terlalu tinggi sehingga hal ini menimbulkan tekanan terhadap pendapatan bank berupa tingginya biaya pemeliharaan kas yang menganggur (idle money) (Rahim, 2008). FDR hanya boleh diperuntukkan oleh Bank Umum Syariah (BUS), sedangkan LDR hanya boleh diperuntukkan oleh Bank Konvensional.

\section{HIPOTESIS}

Hipotesis adalah dugaan sementara atau kesimpulan sementara atas masalah yang hendak diteliti. Perumusan hipotesis dilakukan berdasarkan pada literatur yang telah ada. Hipotesishipotesis yang dibentuk dalam penelitian ini didasarkan pada penelitian sebelumnya, sehingga diharapkan hipotesis tersebut cukup valid untuk diuji. Berdasarkan dari hasil penelitianpenelitian terdahulu tersebut, maka dalam penelitian ini dirumuskan hipotesis-hipotesis sebagai berikut:

H0 : Diduga tidak ada hubungan antara variabel-variabel CAR, NPF, FDR terhadap profitabilitas Bank BCA Syariah.

H1 : Diduga bahwa variabel CAR secara parsial berpengaruh signifikan terhadap profitabilitas Bank BCA Syariah.

H2 : Diduga bahwa variabel NPF secara parsial berpengaruh signifikan terhadap profitabilitas Bank BCA Syariah.

H3 : Diduga bahwa variabel CAR secara parsial berpengaruh signifikan terhadap profitabilitas Bank BCA Syariah.

H4 : Diduga bahwa variabel CAR, NPF dan FDR secara bersama-sama berpengaruh terhadap profitabilitas Bank BCA Syariah.

\section{METODE PENELITIAN Profitabilitas}

Profitabilitas yang dimaksud dalam penelitian ini adalah meneliti Return on Equity (ROE) yaitu merupakan rasio antara laba sesudah pajak terhadap total modal sendiri (equity) yang berasal dari setoran modal pemilik, laba tidak dibagi dan cadangan lain yang dimiliki perusahaan. Semakin tinggi ROE menunjukkan semakin efisien bank menggunakan modal sendiri untuk menghasilkan laba atau keuntungan bersih. Rasio ini menggunakan hubungan antara keuntungan setelah pajak dengan modal sendiri yang digunakan perusahaan. Yang dianggap modal sendiri adalah saham biasa, agio saham, laba ditahan, saham preferen dan cadangan-cadangan lain. Return On Equity diperoleh dari Net Income after tax dibagi equity. Return On Equity (ROE) yaitu rasio untuk mengukur kemampuan perusahaan dalam menghasilkan laba bersih yang dikaitkan dengan pembayaran dividen.

$$
\mathrm{ROE}=\frac{\text { Laba Bersih }}{\text { Total Modal }} \times 100 \%
$$

\section{CAR (Capital Adequacy Ratio)}

Capital Adequacy Ratio (CAR) yaitu rasio besarnya modal yag harus dipenuhi oleh bank. Modal merupakan bagian terpenting bagi perbankan dalam menjalankan kegiatan operasionalnya, karena dengan adanya modal yang ditanamkan terhadap bank maka 
kelangsungan operasional bank juga akan terdorong dalam mengembangkan bisnis perbankannya serta dapat mengurangi kerugian. Bank diharuskan mengantisipasi munculnya risiko, hal ini dikarenakan berbagai bentuk risiko yang besar dapat terjadi pada bank. Selain itu, modal juga digunakan untuk menjaga kepercayaan masyarakat terhadap kinerja bank. Peningkatan pada modal berakibat pada semakin tingginya kesehatan bank yang terkait dengan rasio permodalan (CAR), maka semakin kuat kemampuan bank dalam menanggung risiko kerugian dari setiap kredit atau aktiva yang beresiko.

$$
\mathrm{CAR}=\frac{\text { Modal Bank }}{\text { Total ATMR }} \times 100 \%
$$

\section{NPF (Non Performing Financing)}

Non Performing Financing (NPF) merupakan rasio yang digunakan untuk mengukur risiko terhadap kredit yang disalurkan dengan membandingkan pembiayaan bermasalah dengan jumlah pembiayaan yang disalurkan. NPF diperuntukkan bagi bank syariah, sementara NPL (Non Performing Loan) diperuntukkan bagi bank umum. Apabila semakin tinggi rasio NPF, maka semakin buruk kualitas pembiayaan pada bank tersebut.

Tingginya NPF menunjukkan bahwa bank tersebut tidak profesional dalam mengelola pembiayaan, sehingga hal ini memberikan indikasi bahwa tingkat risiko atas pemberian pembiayaan pada bank tersebut cukup tinggi searah dengan NPF yang dihadapi. Pembiayaan merupakan sektor terbesar dalam mendorong pendapatan sebuah bank, sehingga semakin tinggi pembiayaan bermasalah pada Bank BCA Syariah, maka pendapatan yang diterima oleh bank tersebut akan berkurang, hal ini dapat mengakibatkan menurunnya profitabilitas pada Bank BCA Syariah.

$$
\mathrm{NPF}=\frac{\text { Pembiayaan Bermasalah }}{\text { Total Pembiayaan }} \times 100 \%
$$

\section{FDR (Financing to Deposit Ratio)}

Financing to Deposit Ratio (FDR) merupakan kemampuan bank dalam menyalurkan dananya kepada pihak yang membutuhkan modal. FDR yaitu perbandingan antara besarnya pinjaman atau pembiayaan yang diberikan pada nasabah dengan jumlah dana yang dihimpun oleh bank syariah. FDR diperuntukkan bagi bank syariah, sementara LDR (Loan to Deposit Ratio) diperuntukkan bagi bank umum. Tinggi rendahnya rasio FDR menunjukkan tingkat likuiditas bank syariah tersebut.

Semakin tinggi dana yang disalurkan bank syariah dalam bentuk pembiayaan, maka semakin tinggi pula kemampuan bank syariah dalam memberikan pinjaman. Hal ini berdampak pada peningkatan pendapatan, sehingga keuntungan perbankan syariah semakin meningkat. Namun, apabila pembiayaan yang disalurkan oleh bank syariah tersebut rendah, maka dapat dikatakan bahwa tingkat likuiditas bank syariah terlalu tinggi sehingga hal ini menimbulkan tekanan terhadap pendapatan bank berupa tingginya biaya pemeliharaan kas yang menganggur (idle money). 


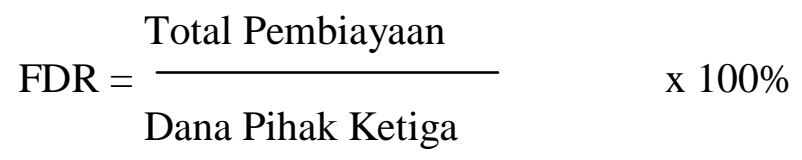

\section{Populasi dan Sampel}

Populasi yang digunakan dalam penelitian ini adalah lembaga keuangan syariah yaitu bank BCA Syariah periode tahun 2010-2017. Teknik pengambilan sampel dalam penelitian ini menggunakan metode secara purposive sampling yaitu metode dimana pemilihan sampel pada karakteristik populasi yang sudah diketahui sebelumnya dengan kriteria sebagai berikut:

a. Bank BCA Syariah merupakan Bank Umum Syariah (BUS).

b. Bank BCA Syariah tersebut membuat laporan keuangan triwulan pada periode 2010-2017 dan telah dipublikasikan oleh Bank Indonesia.

c. Data untuk penelitian tersedia antara tahun 2010-2017 dalam bentuk laporan keuangan triwulan yaitu terdapat 30 sampel.

\section{Jenis dan Sumber Data}

Penelitian ini merupakan studi empiris yang dilakukan pada lembaga keuangan bank BCA Syariah dari tahun 2010 sampai dengan tahun 2017. Data laporan keuangan triwulan yang telah dipublikasikan oleh Bank Indonesia pada periode tahun 2010-2017. Data tersebut diperoleh dari website resmi dari situs perbankan yaitu www.bcasyariah.co.id yang telah disediakan dalam profil bank BCA Syariah.

\section{Teknik Pengumpulan Data}

Teknik pengumpulan data yang digunakan dalam penelitian ini menggunakan data sekunder berupa studi dokumentasi. Metode dokumentasi merupakan teknik pengumpulan data yang dilakukan dengan cara mengumpulkan informasi-informasi berdasarkan sumber data yang berwujud data sekunder atau data yang sebelumnya telah tersedia (Sugiyono, 2010). Data tersebut diperoleh dari Laporan Keuangan Triwulan I sampai Triwulan IV dari tahun 2010-2017 pada bank BCA Syariah melalui website resmi perbankan yaitu www.bcasyariah.co.id dan referensi-referensi yang berkaitan dengan masalah dalam skripsi ini.

\section{TEKNIK ANALISIS \\ Uji Asumsi Klasik}

Model regresi linier berganda (multiple regression) dapat disebut sebagai model yang baik jika model tersebut memenuhi beberapa asumsi yang kemudian disebut dengan asumsi klasik. Menurut Ghozali (2011: 105) uji asumsi klasik yang harus dilakukan terhadap suatu model regresi tersebut diantaranya adalah uji normalitas, autokorelasi, multikolinieritas dan heterokedastisitas.

\section{Uji Normalitas}

Uji normalitas digunakan untuk menguji apakah model regresi mempunyai distribusi normal ataukah tidak. Asumsi normalitas merupakan persyaratan yang sangat penting pada pengujian 
kebermaknan (signifikansi) koefisien regresi. Model regresi yang baik adalah model regresi yang memiliki distribusi normal atau mendekati normal, sehingga layak dilakukan pengujian secara statistik. Uji normalitas bertujuan untuk menguji apakah dalam model regresi, variabel pengganggu atau residual memiliki distribusi normal (Ghozali, 2011).

Pengujian normalitas dalam penelitian ini dilakukan dengan Kolmogorov-Smirnov untuk mengetahui data yang didistribusi normal, dengan kriteria pengujian sebagai berikut (Ghozali, 2011):

a. Jika probabilitas nilai Z uji K-S signifikan $<0,05$ maka data terdistribusi tidak normal.

b. Jika probabilitas nilai $\mathrm{Z}$ uji K-S signifikan $>0,05$ maka data terdistribusi normal.

\section{Uji Multikolinieritas}

Uji multikolinearitas bertujuan untuk menguji apakah model regresi ditemukan memiliki korelasi antar variabel bebas (variabel independen). Model regresi yang baik seharusnya tidak terjadi multikolinearitas (Ghozali, 2011). Jika terdapat korelasi yang kuat diantara sesama variabel independen maka konsekuensinya adalah koefisien-koefisien regresi menjadi tidak dapat ditaksir, dan nilai standar eror setiap koefisien regresi menjadi tidak terhingga.

Dengan demikian berarti semakin besar korelasi diantara variabel independen, maka tingkat kesalahan dari koefisien regresi semakin besar yang mengakibatkan standar erornya semakin besar pula. Dalam penelitian ini, metode yang digunakan untuk mendeteksi multikolinearitas adalah dengan melihat Variance Inflaction Faktor dan Tolerance Value dengan kriteria:

a. Jika nilai tolerance $>0,10$ dan VIF $<10$, maka dapat diartikan bahwa tidak terdapat multikolinearitas pada penelitian tersebut.

b. Jika nilai tolerance $<0,10$ dan VIF $>10$, maka terjadi gangguan pada penelitian tersebut.

\section{Uji Autokorelasi}

Menurut Ghozali (2011: 106) uji autokorelasi bertujuan untuk menguji adanya korelasi antara kesalahan pengganggu pada periode $t$ dengan kesalahan pengganggu pada periode $\mathrm{t}-1$ (sebelumnya) dalam model regresi autokorelasi muncul karena observasi yang berurutan sepanjang waktu berkaitan satu sama lainnya. Model regresi yang baik adalah regresi yang bebas dari autokorelasi. Salah satu cara untuk mengetahui ada atau tidaknya autokorelasi di dalam model regresi adalah dengan menggunakan uji Durbin-Watson (DW test).

Uji Durbin-Watson digunakan untuk autokorelasi tingkat satu (first order autocorrelation) dan mensyaratkan adanya konstanta intercept dalam model regresi serta tidak ada variabel lag diantara variabel independen (Ghozali, 2011: 106). Untuk mendeteksi gejala autokorelasi digunakan alat uji Durbin Watson (DW test) dimana hipotesis yang akan diuji adalah:

$\mathrm{H}_{0}$ : tidak ada autokorelasi $(\mathrm{r}=0)$

$\mathrm{H}_{1}$ : ada autokorelasi $(\mathrm{r} \neq 0)$

Dengan menggunakan patokan umum dengan kriteria sebagai berikut:

a. Jika angka DW berada dibawah -2 berarti ada autokorelasi positif.

b. Jika angka DW berada di antara -2 dan 2, berarti tidak terdapat autokorelasi.

c. Jika angka DW berada diatas 2 , berarti terdapat autokorelasi negatif.

\section{Uji Heteroskedastisitas}

Uji heteroskedastisitas digunakan untuk mengetahui ada atau tidaknya penyimpangan asumsi klasik heteroskedastisitas, yaitu adanya ketidaksamaan varian dari residual untuk semua 
pengamatan pada model regresi. Cara untuk mendeteksi adanya heterokedastisitas antara lain dengan melihat dari tabel coefficient yaitu dari nilai sig $>0,05$ maka tidak terjadi heterokedastisitas.

\section{Uji Regresi Linier Berganda}

Model regresi berganda adalah teknik analisis regresi yang menjelaskan hubungan antara variabel dependen dengan beberapa variabel independen. Persamaan dari model regresi berganda tersebut, sebagai berikut:

$$
\begin{array}{ll}
\mathrm{Y}=\mathrm{a}+\mathrm{b} 1 \mathrm{X} 1+\mathrm{b} 2 \mathrm{X} 2+\mathrm{b} 3 \mathrm{X} 3+\mathrm{e} \\
\begin{array}{ll}
\text { Keterangan: } & \\
\mathrm{Y} & =\text { Profitabilitas } \\
\mathrm{a} & =\text { Konstanta } \\
\mathrm{X} 1 & =\mathrm{CAR} \\
\mathrm{X} 2 & =\mathrm{NPF} \\
\mathrm{X} 3 & =\mathrm{FDR} \\
\mathrm{e} & =\text { Random error atau variable gangguan } \\
\mathrm{b} 1, \mathrm{~b} 2, \mathrm{~b} 3, \mathrm{~b} 4 & =\text { Koefisien regresi Linear masing-masing variabel }
\end{array}
\end{array}
$$

\section{Uji Parsial (Uji t)}

Uji statistik t menunjukkan seberapa jauh pengaruh masing-masing variabel independen secara individu dalam menerangkan variasi variabel dependen (Ghozali, 2011). Uji statistik t ini dapat dilihat dengan dua cara yaitu yang pertama melihat dari nilai signifikan < alpha yang ditetapkan $(0,05)$. Sedangkan cara yang kedua yaitu dengan membandingkan antara $t$ hitung dan $\mathrm{t}$ tabel. Apabila $\mathrm{t}$ hitung $>\mathrm{t}$ tabel maka variabel independen memiliki pengaruh yang signifikan terhadap variabel dependen (Ghozali, 2006).

\section{Uji Signifikansi Simultan (Uji Statistik F)}

Uji statistik F pada dasarnya menunjukkan apakah semua variabel independen atau bebas yang dimasukkan ke dalam model memiliki pengaruh secara bersama-sama terhadap variabel dependen atau terikat (Ghozali, 2006). Uji statistik F ini dapat dilihat dengan dua cara yaitu yang pertama melihat dari nilai signifikan < alpha yang ditetapkan $(0,05)$. Sedangkan cara yang kedua yaitu dengan membandingkan antara F-hitung dan F-tabel. Apabila F-hitung > F-tabel maka variabel independen secara bersama-sama memiliki pengaruh yang signifikan terhadap variabel dependen (Ghozali, 2006).

\section{Uji Koefisien Determinasi}

Koefisien determinasi pada nantinya mengukur seberapa jauh kemampuan model dalam menerangkan variasi dependen. Nilai koefisien determinasi adalah antara $0-1$. Nilai Adj $R^{2}$ yang mendekati 1 berarti variabel-variabel independen memberikan hampir semua informasi yang dibutuhkan untuk memprediksi variasi variabel (Ghozali, 2006: 87). 


\section{HASIL DAN PEMBAHASAN}

\section{Pengaruh CAR Terhadap ROE}

Hasil uji t terhadap variabel CAR memperoleh nilai signifikansi $=0,000<0,05 . P$-value $<\alpha$ yaitu $0,000<0,05$, maka $\mathrm{H} 0$ ditolak dan $\mathrm{H} 1$ diterima. Cara yang kedua yaitu membandingkan antara $t_{-h i t u n g}$ dan $t_{\text {tabel }}$. Apabila $t_{\text {-hitung }}$ lebih besar daripada $t_{-t a b e l}$ maka variabel independen berpengaruh terhadap variabel dependen, dalam penelitian ini nilai $t$ tabel $^{2}$ 2,05553, variabel CAR nilai t-hitung sebesar 4,206>2,05553 artinya CAR secara statistik berpengaruh terhadap profitabilitas bank BCA Syariah periode 2010-2017.

\section{Pengaruh NPF Terhadap ROE}

Hasil uji t terhadap variabel NPF memperoleh nilai signifikansi $=0,105>0,05 . P$-value $<\alpha$ yaitu 0,105 > 0,05, maka $\mathrm{H} 0$ diterima dan $\mathrm{H} 2$ ditolak. Cara yang kedua yaitu membandingkan antara $t_{\text {-hitung }}$ dan $\mathrm{t}_{\text {-tabel}}$. Apabila $\mathrm{t}_{\text {-hitung }}$ lebih besar daripada $\mathrm{t}_{\text {-tabel }}$ maka variabel independen berpengaruh terhadap variabel dependen, dalam penelitian ini nilai $t_{\text {tabel }} 2,05553$, variabel NPF nilai t-hitung sebesar 1,681 < 2,05553 maka artinya NPF secara statistik tidak berpengaruh terhadap profitabilitas bank BCA Syariah periode 2010-2017.

\section{Pengaruh FDR Terhadap ROE}

Hasil uji t terhadap variabel FDR memperoleh nilai signifikansi $=0,362>0,05 . P$-value $<\alpha$ yaitu 0,362 >0,05, maka H0 diterima dan H3 ditolak. Cara yang kedua yaitu membandingkan antara $\mathrm{t}_{\text {-hitung }}$ dan $\mathrm{t}_{\text {-tabel }}$. Apabila $\mathrm{t}_{\text {-hitung }}$ lebih besar daripada $\mathrm{t}_{\text {-tabel }}$ maka variabel independen berpengaruh terhadap variabel dependen, dalam penelitian ini nilai $t_{\text {tabel }}$ 2,05553, Variabel FDR nilai t-hitung sebesar $0,929<2,05553$ maka artinya FDR secara statistik tidak berpengaruh terhadap profitabilitas bank BCA Syariah periode 2010-2017.

\section{Pengaruh CAR, NPF, FDR Terhadap ROE}

Nilai $\mathrm{F}_{\text {-hitung }}$ sebesar 11,369 dengan probabilitas $0,000<0,05$, atau $\mathrm{F}_{\text {-hitung }}$ 11,369 lebih besar daripada nilai $\mathrm{F}_{\text {-tabel }}$ sebesar 2,98. $\mathrm{F}_{\text {-hitung }}$ lebih besar daripada $\mathrm{F}_{\text {-tabel }}$ yaitu 11,369> 2,89 artinya variabel CAR, NPF, FDR secara bersama-sama berpengaruh terhadap profitabilitas pada bank BCA Syariah tahun 2010-2017.

\section{KESIMPULAN DAN SARAN}

Berdasarkan hasil penelitian yang telah dilakukan, maka dapat dibuat kesimpulan sebagai berikut:

1. CAR berpengaruh secara parsial terhadap ROE, artinya besar kecilnya CAR akan mempengaruhi besar kecilnya ROE.

2. NPF tidak berpengaruh secara parsial terhadap ROE, artinya besar kecilnya NPF tidak akan mempengaruhi besar kecilnya ROE.

3. FDR tidak berpengaruh secara parsial terhadap ROE, artinya besar kecilnya FDR tidak akan mempengaruhi besar kecilnya ROE.

4. CAR, NPF, dan FDR berpengaruh secara bersama-sama (simultan) terhadap ROE. 


\section{Keterbatasan dan Saran}

Keterbatasan dalam penelitian ini adalah dalam penelitian ini hanya mengambil satu populasi saja yaitu Bank BCA Syariah dengan mengambil sampel sebanyak 30 sampel dari laporan keuangan triwulan tahun 2010-2017. Variabel yang digunakan dalam penelitian ini hanya 3 variabel, sehingga diharapkan dalam penelitian selanjutnya dapat memperbanyak variabel. Penelitian ini hanya dibatasi rasio profitabilitas perusahaan yang diwakili oleh rasio keuangan yaitu ROE.

Saran yang disampaikan dalam penelitian ini adalah penelitian selanjutnya dapat menambah lebih banyak populasi yang akan diteliti berikutnya, menambahkan sampel sehingga dapat menggambarkan kondisi yang sebenarnya, menambah variabel lainnya karena sangat dimungkinkan ada variabel lainnya yang lebih berpengaruh terhadap profitabilitas dan menambah rasio profitabilitas perusahaan agar dapat membandingkan rasio satu dengan rasio yang lainnya.

\section{DAFTAR PUSTAKA}

Arifin, Zainul. 2003. Dasar-dasar Manajemen Bank Syariah, Cet. 2. Jakarta: Alva Bet.

Azmi, Intan Zahria. 2014. Pengaruh Inflasi, CAR, NPF terhadap Profitabilitas Perbankan Syariah di Indonesia Periode Triwulan I 2008-Triwulan IV 2008. Surakarta: Universitas Muhammadiyah Surakarta.

Bank Indonesia. 1998. Undang-Undang Nomor 10 Tahun 1998 tentang Perubahan Atas Undang-Undang Nomor 7 Tahun 1992 Tentang Perbankan. Jakarta: Bank Indonesia. (http://www.bi.go.id, diakses 12 Januari 2018).

Bank Indonesia. 2008. Undang-Undang Nomor 21 Tahun 2008 Tentang Perbankan Syariah. Jakarta: Bank Indonesia. (http://www.bi.go.id, diakses 12 Januari 2018).

Berita Online. https://www.kompasiana.com/ikayulip/perkembangan-bank-syariah-di-indonesia 572ac4d3f1927349059f6b6f. Diakses tanggal 12 Januari 2018.

Ghozali Imam. 2006. Aplikasi. Analisis Multivariat Dengan Program SPSS. Cet 1V. Semarang : Badan Penerbit Universitas Diponegoro.

Ghozali, Imam. 2007. Aplikasi Analisis Multivariate dengan Program SPSS. Semarang: Badan Penerbit Universitas Diponegoro.

Ghozali, Imam. 2011. Aplikasi Analisis Dengan Program IBM SPSS, Edisi kelima. Semarang: Badan Penerbit Universitas Diponegoro.

Hasibuan, Melayu S.P. 2006. Manajemen Dasar, Pengertian, dan Masalah, Edisi Revisi. Jakarta: PT Bumi Aksara.

Kasmir. 2009. Dasar-Dasar Perbankan. Jakarta: PT.Rajagrafindo Persada.

Kuncoro, Mudrajad dan Suhardjono. 2002. Manajemen Perbankan Teori dan Aplikasi. Yogyakarta; BPFE UGM. 
Mahmud, Amir, Rukmana. 2010. Akuntansi Syariah: Teori Kebijakan, dan Studi Empiris di Indonesia. Jakarta: Erlangga.

Pramudhito, R. Ade Sasongko. 2014. Analisis Pengaruh CAR, NPF, BOPO, FDR, dan NCOM terhadap Profitabilitas Bank Umum Syariah di Indonesia. Semarang: Universitas Diponegoro.

Pratiwi, Dhian Dayinta. 2012. Pengaruh CAR, BOPO, NPF, dan FDR terhadap Return On Asset (ROA) Bank Umum Syariah. Semarang: Universitas Diponegoro.

Rahim dan Irpa. 2008. Analisa Efisiensi Operasional terhadap Profitabilitas pada Bank Umum Syariah dan Unit Syariah (Studi Kasus BSM dan BNI Syariah). Jurnal Bisnis \& Manajemen. Vol.4, No.3 (2008).

Ruslim. 2012. “Analisis Pengaruh Capital Adequancy Ratio (CAR), Non Performing Loan (NPL), dan Loan to Deposit Ratio (LDR) Terhadap Return On Asset (ROA) Pada Bank Umum Syariah Yang Terdaftar Di Bank Indonesia”.

Sinungan, Muchdarsyah. 2000. Manajemen Dana Bank. Jakarta: PT Bumi Aksara.

Sofyan. 2003. Manajemen Laba Perusahaan. Edisi Kelima. Jakarta: Erlangga.

Sugiyono. 2010. Metode Penelitian Bisnis. Bandung: Alfabeta.

Sumitro, Muchdarsyah. 2002. Manajemen Dana Bank. Jakarta: PT. Bumi Aksara.

Susanto, Bob. (2015). Pengertian Lembaga Keuangan Menurut Para Ahli. http://www.spengetahuan.com/2015/03/pengertian-lembaga-keuangan menurut-paraahli.html. Diakses 11 April 2015.

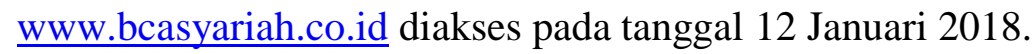

Zuhri, Mohammad. 1996. Riba dalam Al-Qur'an dan Masalah Perbankan. Jakarta: Raja Grafinda Persada. 